\title{
Sistem Informasi Geografi (SIG) Pencarian Lokasi Tambal Ban dengan Pemanfaatan Teknologi GPS
}

\author{
Desy Ika Puspitasari ${ }^{1}$, Zaenuddin ${ }^{2}$, Fitrah Yuridka ${ }^{3}$ \\ ${ }^{1,2,3}$ Program Studi Teknik Informatika Fakultas Teknologi Informasi Universitas Islam Kalimantan MAB \\ E-mail: smile4desyka@email.com
}

\begin{abstract}
The occurrence of a tire leak in the middle of a trip can often be caused by many things, such as being hit by a sharp object, the age of the tire is too old, leaking in the former patches, or it can be caused by others. These factors make vehicle users panic and think to immediately find the nearest tire repair location. Almost everyone has a smartphone where there is a Google Map application by utilizing GPS technology so as not to get lost when driving, with GPS technology can be estimated the distance between one location and another. The purpose of this study is to produce a GIS mobile application that provides a tire patch location search feature with information, so that it is expected to be useful for vehicle users if they experience a tire accident or erupt on the road. The workshop information that is presented is the opening / closing time of the workshop, there are nitrogen added facilities or not, tubeless tire patches, can repair motorcycle tire patches or can also tire the car and the contact of the workshop owner, so you can directly contact the nearest tire patch. The results of testing the user's response to the use of the application indicate that the application is useful.
\end{abstract}

Keywords: GIS, mobile application, searching location

\begin{abstract}
ABSTRAK
Terjadinya kebocoran ban di tengah perjalanan sering dapat disebabkan oleh banyak hal, seperti terkena benda tajam, usia ban terlalu tua, bocor di bekas tambalan, atau bisa juga disebabkan oleh lainnya. Faktor-faktor ini membuat pengguna kendaraan panik dan berpikir untuk segera mencari lokasi perbaikan ban terdekat. Hampir semua orang memiliki smartphone di mana ada aplikasi Google Map dengan memanfaatkan teknologi GPS agar tidak tersesat saat berkendara, dengan teknologi GPS dapat diperkirakan jarak antara satu lokasi dengan lokasi lain. Salah satu teknologi Sistem Informasi Geografis adalah mobile SIG. Tujuan dari penelitian ini adalah menghasilkan aplikasi mobile SIG yang menyediakan fitur pencarian lokasi tambal ban disertai informasinya, sehingga diharapkan akan berguna bagi pengguna kendaraan jika mengalami kecelakaan ban atau meletus di jalan. Informasi bengkel yang disajikan ialah waktu buka/tutup bengkel, terdapat fasilitas tambah nitrogen atau tidak, tambal ban tubeless, dapat memperbaiki tambal ban motor saja atau juga bisa ban mobil serta kontak pemilik bengkel, sehingga dapat langsung menghubungi tambal ban terdekat. Hasil pengujian tanggapan pengguna terhadap penggunaan aplikasi menunjukkan bahwa aplikasi bermanfaat.
\end{abstract}

Kata kunci: Aplikasi mobile, SIG, pencarian lokasi

\section{PENDAHULUAN}

Seringkali terjadinya kebocoran ban ditengah perjalanan dapat disebabkan banyak hal, misal terkena benda tajam, umur ban sudah terlalu tua, bocor pada bekas tambalan, atau bisa juga disebabkan karena faktor lain. Hal ini membuat pengguna kendaraan panik dan berfikir untuk segera mencari lokasi tambal ban terdekat.
Teknologi Sistem Informasi Geografi (SIG) berkembang sangat pesat, salah satunya ialah mobile GIS (Geographic Information System). Mobile GIS dapat digunakan untuk menangkap, menyimpan, update, manipulasi, analisa dan menampilkan sistem informasi geografi secara mudah [1]. Fitur pencarian merupakan fitur yang paling penting dalam aplikasi apapun, apalagi dalam melakukan pencarian lokasi pada peta, 
dapat dipastikan pengguna mengalami kesulitan memilih titik lokasi, karena pasti menggesergeser peta google/ google map [2].

Beberapa penelitian terkait yang dijadikan acuan, diantaranya penelitian yang berjudul Aplikasi Pencarian Lokasi Terdekat Pelayanan Kesehatan Berbasis Android Di Kota Yogyakarta [3]. Berdasarkan penelitian tersebut, dihasilkan sebuah aplikasi yang mampu membantu masyarakat khususnya warga Yogyakarta dalam mencari pelayanan kesehatan dengan rute terdekat. Judul penelitian lainnya adalah Pemanfaatan GPS Tracker Dalam Penyediaan Informasi Pada Aplikasi Berbasis Android (Studi Kasus: Bus Trans Jakarta Koridor 6 dan 6A) [4]. Metodologi yang digunakan dalam pembuatan aplikasi ini adalah dengan model waterfall, selanjutnya ialah penelitian yang berjudul Pemanfaatan Google Map API pada Aplikasi Pencarian Lokasi Department Store berbasis Web, yang memvisualisasikan jalur dari tempat asal ke departement store dan dilengkapi navigasi arah, terdapat juga perhitungan jarak (kilometer) [5]. Tambahan, terdapat juga penelitian sejenis lainnya dengan judul Inovasi Peta Digital Lokasi Bengkel Tambal Ban untuk Smartphone, dengan berbasiskan teknologi GPS [6]. Hasil analisa peneliti terhadap referensi penelitian terkait diatas adalah adanya persamaan teknologi yang digunakan untuk membuat aplikasi berbasis pencarian lokasi dengan Google Map API. Perbedaan dengan penelitian-penelitian sebelumnya adalah belum terdapat informasi apa saja yang disediakan oleh bengkel, misalnya bengkel tersebut melayani ban tubeless atau tidak, terdapat nitrogen atau tidak, dan bisa memperbaiki ban mobil juga atau tidak.

Kota Banjarbaru memiliki 5 kecamatan dan 20 kelurahan, serta menjadi pusat pemerintahan Provinsi Kalimantan Selatan. Mengingat banyaknya permukiman apalagi sekarang banyak pembangunan komplek perumahan di Banjarbaru, hal ini secara otomatis membuat banyaknya jalan-jalan baru yang dibuka oleh pemerintah setempat. Sebenarnya hal ini dapat menjadi peluang bagi pengusaha tambal ban untuk membuka lokasi tambal ban dibeberapa tempat, karena sekarang ini masih jarang sekali ditemukannya bengkel atau lokasi tambal ban pada perumahan baru tersebut. Maka yang menjadi pokok permasalahan adalah bagaimana memanfaatkan teknologi SIG untuk merancang aplikasi mobile yang terintegrasi teknologi GPS agar dapat dimanfaatkan para pengguna kendaraan maupun tukang tambal ban sebagai media yang mampu mempertemukan pemilik kendaraan yang mengalami musibah bocor ban dengan jasa-jasa terkait, seperti bengkel dan tambal ban. Tujuan penelitian ini menyediakan pencarian lokasi titik tambal ban serta informasi tentang lokasi dan informasi/kontak tambal ban atau bengkel dengan rute terdekat, sehingga diharapkan dapat bermanfaat bagi pengguna kendaraan jika mengalami musibah ban bocor atau meletus dijalan.

SIG adalah sistem komputer yang digunakan untuk memasukkan, menyimpan, memeriksa, mengintegrasikan, memanipulasi, menganalisa, dan menampilkan data yang berhubungan dengan posisi-posisi permukaan bumi [7]. Sistem Layanan Berbasis Lokasi, atau lebih dikenal dengan Location-Based Service (LBS), menggabungkan antara proses dari layanan mobile dengan posisi geografis dari penggunanya [8]. Poin pentingnya adalah ketika posisi target, di mana sebuah target bisa jadi adalah pengguna LBS itu sendiri atau entitas lain yang tergabung dalam suatu layanan.

Android merupakan sistem operasi yang digunakan pada smartphone android [9]. Android menyediakan dukungan peta seluler (mobile map) dan layanan lokasi yang berisi tampilan peta yang fleksibel dan fungsi kontrol yang mudah digunakan [10]. GPS (Global Positioning Sistem) digunakan untuk petunjuk arah atau sebagai alat navigasi guna mencari suatu lokasi di permukaan bumi dengan bantuan sinyal satelit [11]. Sinyal diterima oleh alat penerima dipermukaan dan digunakan untuk menentukan letak, kecepatan, arah, dan waktu [12]. Pada pelaksanaan survei GPS, strategi pengamatan sangat berperan dalam mencapai kualitas yang baik dari posisi titik - titik GPS. 
Ketelitian posisi dalam beberapa meter (tidak berketelitian tinggi) dan umumnya hanya diperuntukkan bagi keperluan navigasi [13].

Data yang ditangani SIG mempunyai dua bagian penting yaitu informasi lokasi (spasial) dan informasi deskriptif (atribut). Data atribut merupakan data yang mendeskripsikan karakteristik atau fenomena yang dikandung pada suatu objek data dalam peta dan tidak mempunyai hubungan dengan posisi geografi, dapat berupa informasi numerik, foto, narasi, dan lain sebagainya, yang diperoleh dari data statistik, pengukuran lapangan dan sensus, dan lain-lain [14]. Google Maps menawarkan peta yang dapat digeser (panned), diperbesar (zoom in), diperkecil (zoom out), dapat diganti dalam beberapa mode (map, satelite, hybrid, dan lainlain), fitur pencarian rute (routing), penunjuk arah dari suatu objek peta ke objek yang lain (direction), dan juga pencarian tempat (place) [15].

\section{METODE}

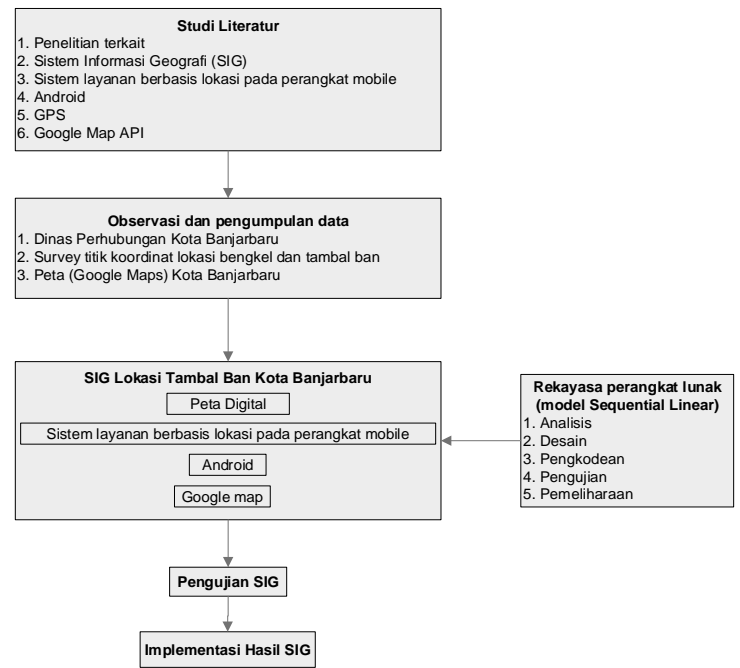

Gambar 1. Desain Tahapan Penelitian

Gambar 1 merupakan tahapan penelitian yang dilakukan. Studi literatur dilakukan dengan mempelajari dan memahami teori-teori yang digunakan, yang menjadi syarat SIG, teori sistem layanan berbasis lokasi pada perangkat mobile, teori Android, GPS dan Google Maps APIs. Data-data tersebut dicari dengan cara mengumpulkan literatur, jurnal, browsing internet, dan bacaan-bacaan yang ada kaitannya dengan topik, baik berupa textbook atau paper. Observasi dilakukan dengan mengadakan penelitian dan peninjauan langsung terhadap permasalahan yang diambil untuk mendapatkan data yang akurat mengenai data peta Kota Banjarbaru, titik koordinat lokasi tambal ban dan bengkel, serta wawancara kebutuhan pengguna kendaraan terhadap SIG serta keterkaitan layanan berbasis lokasi dengan SIG. Hasil dari studi literatur dan observasi ditemukan data yang dibutuhkan untuk SIG, data peta Kota Banjarbaru, titik koordinat lokasi tambal ban/bengkel. Selanjutnya pengembangan perangkat lunak SIG lokasi tambal ban Kota Banjarbaru dengan memanfaatan teknologi GPS.

Metode yang digunakan untuk merancang sistem adalah menggunakan UML (Unified Modeling Language), UML adalah sebuah bahasa yang berdasarkan grafik/ gambar untuk memvisualisasi, melakukan spesifikasi, membangun, dan pendokumentasian dari sebuah sistem pengembangan perangkat lunak berbasis OO (Object-Oriented) [16]. Dalam rekayasa perangkat lunak menggunakan model sequential linear dengan atribut dari data lokasi tambal ban/bengkel serta informasi kontak tambal ban/bengkel, serta menerapkan sistem layanan berbasis lokasi yang hasilnya ditampilkan pada perangkat mobile. Tahap selanjutnya hasil dari pengembangan perangkat lunak dilakukan pengujian SIG lokasi tambal ban/bengkel Kota Banjarbaru dengan cara mengoperasikan sistem secara berulang-ulang.

Setelah tahap pengujian rekayasa perangkat lunak selesai, tahap selanjutnya adalah mengimplementasi hasil pengujian sistem yang akan digunakan oleh pengendara motor/mobil serta pemilik tambal ban/bengkel di Kota Banjarbaru. Koneksi internet menggunakan mini wifi/GPRS-GSM antena. UML sebagai model perancangan sistem. Lokasi penelitian adalah tempat-tempat tambal ban 
maupun bengkel, sebagai pengambilan titik koordinat lokasi.

Metode pengumpulan data yang digunakan dalam penelitian ini adalah: (a) wawancara metode pengumpulan data dengan cara mengadakan tanya jawab yang dilakukan secara langsung kepada para pemilik tambal ban dan bengkel di Banjarbaru yang berkaitan dengan fasilitas yang diberikan, misal apakah pada tambal ban tersebut terdapat fasilitas bengkel juga, apakah terdapat tambal ban tubeless, dan lain sebagainya yang akan menjadi data atribut objek tambal ban; (b) observasi pengumpulan data melalui pengamatan dan pencatatan terhadap titik koordinat (point) lokasi tambal ban/bengkel beserta data atributnya. Pengamatan dilakukan langsung secara observasi pada 5 kecamatan kota Banjarbaru, yang terdiri dari 20 kelurahan; (c) studi pustaka pengumpulan data dengan membaca serta mempelajari dokumen-dokumen, literatur, jurnal, dan buku-buku yang berhubungan dengan obyek penelitian, sebagai landasan teori dan kerangka pemikiran dalam penelitian dan untuk mencari metodologi yang sesuai serta membandingkan antara teori yang ada dengan fakta yang terjadi di lapangan.

Data yang digunakan dalam penelitian ini: (1) Data spasial, yaitu koordinat $\mathrm{x}$ dan koordinat y titik lokasi tambal ban/bengkel; (2) Data atribut yang dikumpulkan yaitu nama kelurahan, nama bengkel, nama pemilik, No.Hp, fasilitas, jam buka/tutup, foto lokasi. Berikut ini adalah data kelurahan dan kecamatan yang ada di Banjarbaru. Dari data Tabel 1 terdapat sebanyak 143 titik koordinat tambal ban/bengkel dalam 5 kecamatan yang terbagi 20 kelurahan. Tabel 2 menjelaskan atribut lokasi tambal ban/bengkel. Pengambilan data lokasi titik koordinat tambal ban tersebut tidak dapat dikatakan akurat $100 \%$, jarak tempuh yang dilalui bisa jadi lebih dekat atau lebih jauh. Hal ini pernah dilakukan dalam penelitian Hamman [17] yang melakukan perbandingan pengukuran jarak tempuh sepeda motor antara Google Maps, dan modul GPS berbasis mikrokontroler. Hasil pengujian menyimpulkan terdapat persentase error, namun tidak mencapai 5\% dan bersifat fluktuatif.

Tabel 1. Kelurahan dan Kecamatan di Banjarbaru

\begin{tabular}{|c|c|c|}
\hline No. & Kecamatan & Kelurahan \\
\hline 1 & $\begin{array}{l}\text { Banjarbaru } \\
\text { Selatan }\end{array}$ & $\begin{array}{l}\text { Guntung Paikat } \\
\text { (Kodepos : 70713) }\end{array}$ \\
\hline 2 & $\begin{array}{l}\text { Banjarbaru } \\
\text { Selatan }\end{array}$ & $\begin{array}{l}\text { Kemuning } \\
\text { (Kodepos : 70714) }\end{array}$ \\
\hline 3 & $\begin{array}{l}\text { Banjarbaru } \\
\text { Selatan }\end{array}$ & $\begin{array}{l}\text { Loktabat Selatan } \\
\text { (Kodepos : 70714) }\end{array}$ \\
\hline 4 & $\begin{array}{l}\text { Banjarbaru } \\
\text { Selatan }\end{array}$ & $\begin{array}{l}\text { Sei/Sungai Besar } \\
\text { (Kodepos : 70714) }\end{array}$ \\
\hline 5 & $\begin{array}{l}\text { Banjarbaru } \\
\text { Utara }\end{array}$ & $\begin{array}{l}\text { Komet } \\
\text { (Kodepos : 70714) }\end{array}$ \\
\hline 6 & $\begin{array}{l}\text { Banjarbaru } \\
\text { Utara }\end{array}$ & $\begin{array}{l}\text { Loktabat Utara } \\
\text { (Kodepos : 70714) }\end{array}$ \\
\hline 7 & $\begin{array}{l}\text { Banjarbaru } \\
\text { Utara }\end{array}$ & $\begin{array}{l}\text { Mentaos } \\
\text { (Kodepos : 70714) }\end{array}$ \\
\hline 8 & $\begin{array}{l}\text { Banjarbaru } \\
\text { Utara }\end{array}$ & $\begin{array}{l}\text { Sei/Sungai Ulin } \\
\text { (Kodepos : 70714) }\end{array}$ \\
\hline 9 & Cempaka & $\begin{array}{l}\text { Palam } \\
\text { (Kodepos : 70731) }\end{array}$ \\
\hline 10 & Cempaka & $\begin{array}{l}\text { Bangkal } \\
\text { (Kodepos : 70732) }\end{array}$ \\
\hline 11 & Cempaka & $\begin{array}{l}\text { Cempaka } \\
\text { (Kodepos : 70733) }\end{array}$ \\
\hline 12 & Cempaka & $\begin{array}{l}\text { Sei/Sungai Tiung } \\
\text { (Kodepos : 70734) }\end{array}$ \\
\hline 13 & Landasan Ulin & $\begin{array}{l}\text { Guntung Payung } \\
\text { (Kodepos : 70721) }\end{array}$ \\
\hline 14 & Landasan Ulin & $\begin{array}{l}\text { Guntung Manggis } \\
\text { (Kodepos : 70724) }\end{array}$ \\
\hline 15 & Landasan Ulin & $\begin{array}{l}\text { Landasan Ulin Timur } \\
\text { (Kodepos : 70724) }\end{array}$ \\
\hline 16 & Landasan Ulin & $\begin{array}{l}\text { Syamsudin Noor } \\
\text { (Kodepos : 70724) }\end{array}$ \\
\hline 17 & Liang Anggang & $\begin{array}{l}\text { Landasan Ulin Barat } \\
\text { (Kodepos : 70722) }\end{array}$ \\
\hline 18 & Liang Anggang & $\begin{array}{l}\text { Landasan Ulin Tengah } \\
\text { (Kodepos : 70723) }\end{array}$ \\
\hline 19 & Liang Anggang & $\begin{array}{l}\text { Landasan Ulin Selatan } \\
\text { (Kodepos : 70724) }\end{array}$ \\
\hline 20 & Liang Anggang & $\begin{array}{l}\text { Landasan Ulin Utara } \\
\text { (Kodepos : 70724) }\end{array}$ \\
\hline
\end{tabular}


Tabel 2 Data Atribut Lokasi Tambal Ban/Bengkel

\begin{tabular}{|c|c|c|c|c|c|c|c|c|}
\hline No. & Kelurahan & $\begin{array}{c}\text { Nama } \\
\text { Bengkel - } \\
\text { Pemilik } \\
\end{array}$ & No.HP & Fasilitas & $\begin{array}{l}\text { Jam } \\
\text { buka- } \\
\text { tutup }\end{array}$ & Koord.X & Koord.Y & Foto \\
\hline 1. & $\begin{array}{l}\text { Landasan } \\
\text { Ulin } \\
\text { Tengah }\end{array}$ & $\begin{array}{l}\text { Bengkel } \\
\text { Yulianto } \\
- \\
\text { Yulianto }\end{array}$ & $\begin{array}{l}08164515 \\
\text { XXXX }\end{array}$ & $\begin{array}{l}\text { - Tambal ban motor } \\
\text { - Tubeless } \\
\text { - Service } \\
\text { - Sparepart }\end{array}$ & $\begin{array}{l}08.00- \\
19.00\end{array}$ & $\begin{array}{l}-3,444077 \\
83436259\end{array}$ & $\begin{array}{l}114,7400 \\
50546824\end{array}$ & \\
\hline 2. & $\begin{array}{l}\text { Landasan } \\
\text { Ulin } \\
\text { Tengah }\end{array}$ & $\begin{array}{l}\text { Zainudin } \\
\text { Motor - } \\
\text { Zainudin }\end{array}$ & $\begin{array}{l}08125312 \\
\text { XXXX }\end{array}$ & $\begin{array}{l}\text { - Tambal ban motor } \\
\text { - Tubeless } \\
\text { - Service } \\
\text { - Sparepart }\end{array}$ & $\begin{array}{l}08.00- \\
17.00\end{array}$ & $\begin{array}{l}-3,444190 \\
28360774\end{array}$ & $\begin{array}{l}114,7399 \\
64045584\end{array}$ & \\
\hline 3. & $\begin{array}{l}\text { Landasan } \\
\text { Ulin } \\
\text { Tengah }\end{array}$ & $\begin{array}{l}\text { Sulawesi } \\
\text { Motor - } \\
\text { Rahmad }\end{array}$ & $\begin{array}{l}08534836 \\
\text { XXXX }\end{array}$ & $\begin{array}{l}\text { - Tambal ban motor } \\
\text { - Service } \\
\text { - Sparepart }\end{array}$ & $\begin{array}{l}08.00- \\
16.00\end{array}$ & $\begin{array}{r}-3,449575 \\
78688399\end{array}$ & $\begin{array}{l}114,7364 \\
86896872\end{array}$ & \\
\hline 4. & $\begin{array}{l}\text { Landasan } \\
\text { Ulin } \\
\text { Tengah }\end{array}$ & $\begin{array}{l}\text { Bengkel } \\
\text { Isur - } \\
\text { Isur }\end{array}$ & $\begin{array}{l}08215022 \\
\text { XXXX }\end{array}$ & $\begin{array}{l}\text { - Tambal ban motor } \\
\text { - Service } \\
\text { - Sparepart } \\
\text { - Nitrogen } \\
\text { - Toilet }\end{array}$ & $\begin{array}{l}08.00- \\
17.00\end{array}$ & $\begin{array}{l}-3,443139 \\
41750335\end{array}$ & $\begin{array}{l}114,7227 \\
30517387\end{array}$ & \\
\hline
\end{tabular}

\section{HASIL DAN PEMBAHASAN}

Ilustrasi pencarian rute tambal ban/ bengkel terdekat ketika kendaraan bermotor mengalami kebocoran ban atau kempes ban melalui smartphone disajikan pada Gambar 2.

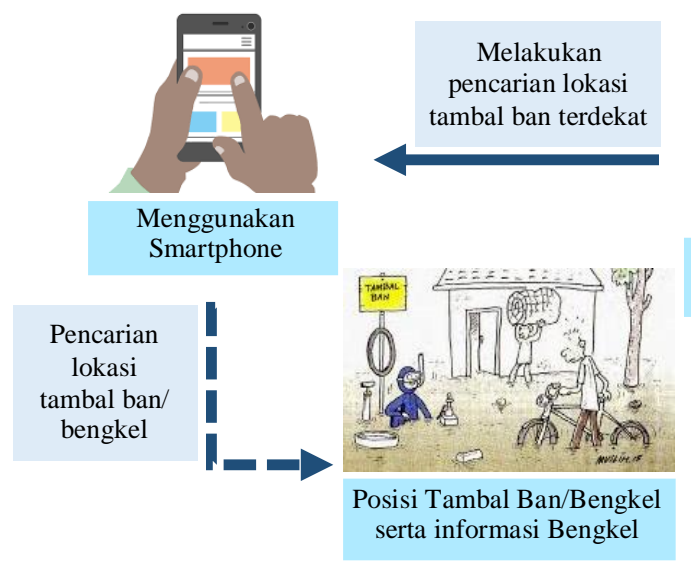

Pada aplikasi android mobile, pengendara motor dapat memilih lokasi tambal ban atau bengkel terdekat serta melihat informasi bengkel. Selanjutnya akan ditampilkan pada peta Google Maps terkait posisi pengendara motor dan rute yang dilalui untuk menuju lokasi tambal ban.

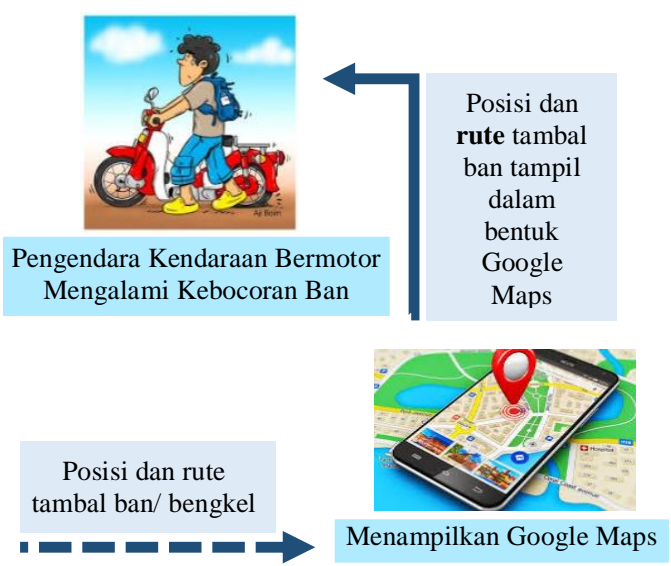

Gambar 2. Desain Alur Sistem

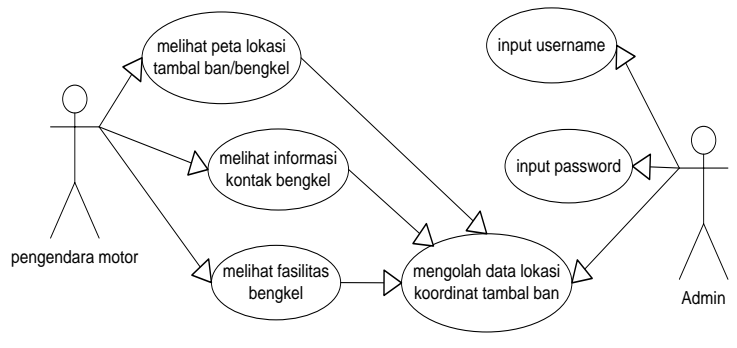

Gambar 2. Use Case Diagram Sistem
Alur use case diagram seperti pada Gambar 3 menunjukkan bahwa dari sistem pencarian lokasi tambal ban dimana terdapat 2 aktor, yaitu pengendara motor dan admin. Admin disini sebagai user yang dapat melakukan pengolahan data spasial titik lokasi tambal ban/bengkel, serta menginputkan informasinya berupa nama bengkel atau tambal 
ban, siapa nama pemiliknya, no.handphone, foto bengkel tersebut, fasilitas apa saja yang dimiliki bengkel tersebut serta kapan waktu buka dan tutup bengkel. Fasilitas yang tersedia disini diberikan pilihan yaitu : apakah terdapat tambal ban mobil juga atau hanya motor, apakah terdapat fasilitas ban tubeless, apakah terdapat nitrogen, kemudian apakah waktu buka bengkel tersebut full 24 jam atau tidak. Perbedaan aktor admin dengan aktor pengendara motor disini ialah hak aksesnya, admin dapat melakukan input dan hapus data (jika pemilik bengkel pindah lokasi bengkelnya), sedangkan pengendara motor hanya dapat melihat informasi lokasi dan fasilitasnya saja.

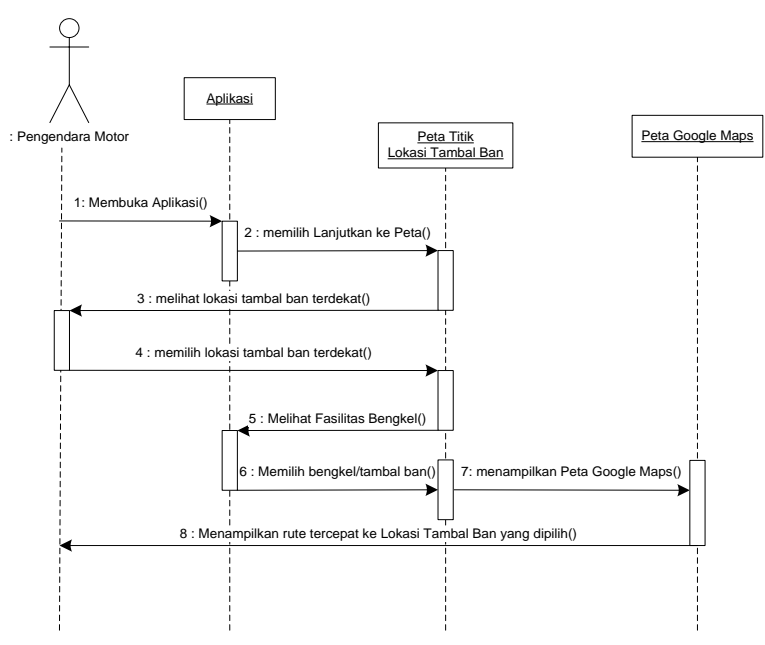

Gambar 3. Sequence Diagram

Sequence diagram atau diagram kegiatan dari pengendara motor tersaji pada Gambar 4, dimana terdapat beberapa objek, yaitu aktor dari pengendara motor, objek aplikasi, peta titik lokasi tambal ban dan peta Google Maps. Pengendara motor memilih menu lanjutkan ke peta untuk melihat peta titik lokasi tambal ban, kemudian pengguna melihat dimana posisi tambal ban terdekat, dan memilihnya, selanjutnya dapat melihat fasilitas bengkel tersebut. Setelah memilih lokasi tambal ban maka rute menuju lokasi dapat ditampilkan dengan menuju ke Peta Google Maps.

Gambar 5(a) menjelaskan activity diagram dari sistem. Dari activity diagram tersebut diketahui bahwa aktivitas pertama yang dilakukan yaitu memilih lokasi tambal ban terdekat. Aktivitas selanjutnya adalah melihat informasi tambal ban yang dipilih, dan dilanjutkan dengan menampilkan peta titik lokasi tambal ban. Peta rute dari posisi pengendara ke lokasi tambal ban yang dipilih ditampilkan merupakan aktivitas selanjutnya.

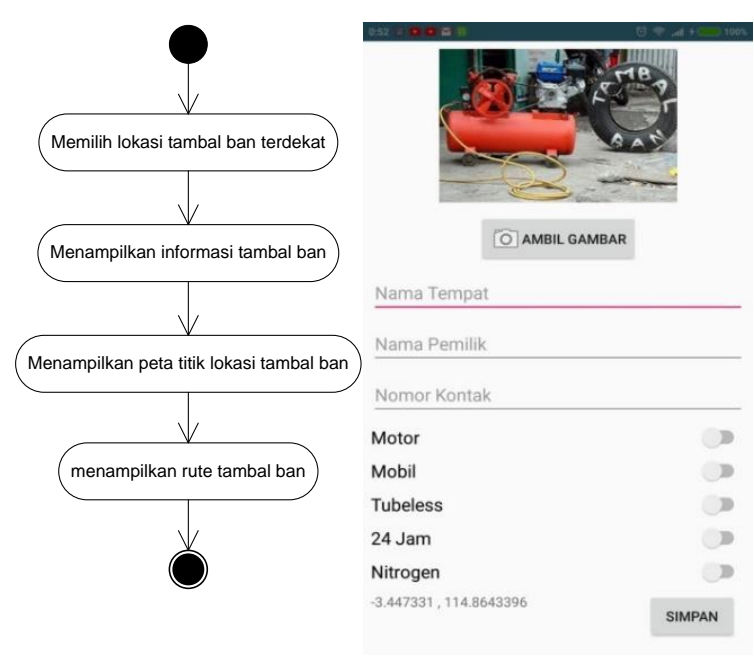

(a)

(b)

Gambar 4. (a) Activity Diagram dan (b) Tampilan Tambah Data Bengkel

Gambar 5(b) menjelaskan penambahan data bengkel. Pengisian informasi tambal ban, seperti foto tambal ban dapat dilakukan dengan memilih tombol ambil gambar, kemudian input nama tempat, nama pemilik tambal ban, nomor kontak serta memilih fasilitas apa saja yang terdapat disana. Apakah terdapat tambal ban motor/ban mobil, terdapat nitrogen, terdapat ban tubeless, terdapat nitrogen, dan apakah tersedia servis tambal ban 24 jam.

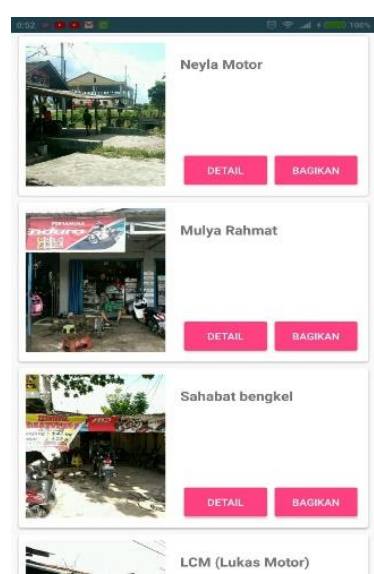

(a)

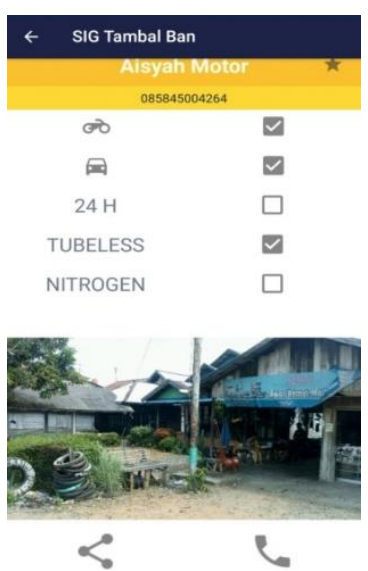

(b)
Gambar 6. (a) Tampilan Foto Lokasi Tambal Ban dan (b) Tampilan Fasilitas Bengkel 
Gambar 6(a) menunjukkan apabila admin telah menambahkan data lokasi tambal ban beserta fotonya, maka datanya tambal ban akan ditampilkan pada menu tampilan foto lokasi tambal ban beserta detail form Fasilitas Bengkel. Gambar 6 (b) menjelaskan tampilan fasilitas bengkel/tambal ban apabila memenuhi fasilitasnya maka akan diberi tanda centang pada kotak pilihan, terdapat logo share untuk menshare lokasi, dan logo telepon jika pengendara akan langsung menghubungi tukang tambal ban.

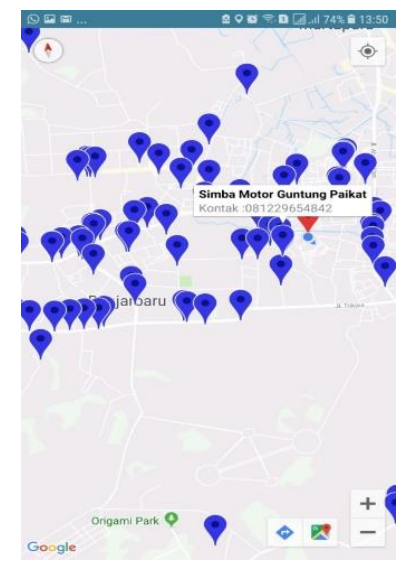

(a)

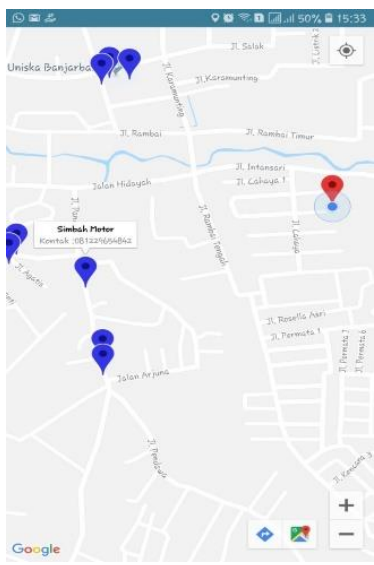

(b)

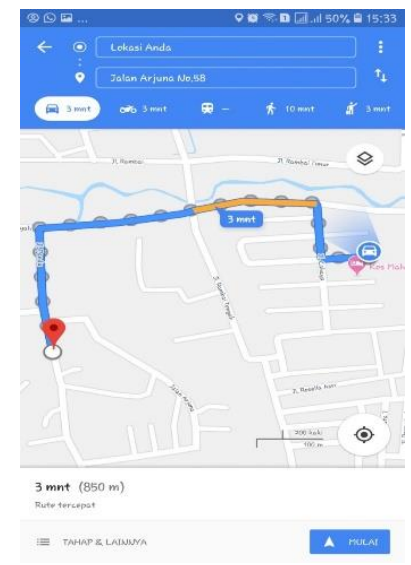

(c)

Gambar 8. (a) Tampilan Titik Lokasi Tambal Ban, (b) Tampilan Button untuk Menuju Arah Lokasi Tambal Ban, dan (c) Tampilan Rute dari Lokasi Asal ke Lokasi Tambal Ban

Gambar 8(a) menjelaskan tampilan titik lokasi tambal ban atau bengkel pada Google Map API, apabila titik lokasi bengkel tersebut dipilih pengguna, maka akan muncul notifikasi "Tekan marker sekali lagi untuk informasi detail" kemudian akan sistem akan menuju ke form fasilitas tambal ban untuk melihat detail fasilitasnya. Gambar 8(b) menjelaskan jika pengguna (dalam gambar tersebut ditandai point merah) akan menuju ke lokasi tambal ban disertai rute, maka memilih lokasi tambal ban terdekat kemudian klik button dengan simbol arah yang berada di pojok kanan bawah, maka sistem akan langsung menampilkan ke bentuk Google Map. Gambar 8(c) merupakan tampilan ke Google Map untuk menunjukkan arah/rute yang harus dilalui pengguna menuju ke lokasi tambal ban terdekat. Dari map tersebut ditampilkan juga jarak dan waktu tercepat untuk bisa sampai ke lokasi. Pada akhir sesi, diberikan pengujian kuisioner dengan empat pilihan jawaban, yaitu: TB untuk Tidak Bermanfaat, CB untuk Cukup Bermanfaat, B untuk Bermanfaat dan SB untuk Sangat Bermanfaat. Tabel 3 menunjukkan hasil pengujian kuisioner.
Tabel 3. Hasil Pertanyaan Kuisioner Aplikasi

\begin{tabular}{|c|c|c|c|c|c|}
\hline No. & Pertanyaan & & $\begin{array}{c}\mathrm{Ni} \\
\mathrm{CB} \\
2\end{array}$ & $\begin{array}{r}\text { lai } \\
\text { B } \\
3\end{array}$ & $\begin{array}{c}\text { SB } \\
4\end{array}$ \\
\hline 1 & $\begin{array}{l}\text { Apakah informasi yang } \\
\text { disediakan oleh aplikasi ini } \\
\text { mudah dimengerti? }\end{array}$ & 0 & 0 & 7 & 7 \\
\hline 2 & $\begin{array}{l}\text { Apakah penggunaan menu } \\
\text { atau fitur aplikasi menu } \\
\text { mudah digunakan? }\end{array}$ & 0 & 1 & 6 & 7 \\
\hline 3 & $\begin{array}{l}\text { Secara keseluruhan apakah } \\
\text { penggunaan aplikasi ini } \\
\text { memuaskan? }\end{array}$ & 0 & 1 & 4 & 9 \\
\hline 4 & $\begin{array}{l}\text { Apakah aplikasi ini sesuai } \\
\text { dengan kebutuhan? }\end{array}$ & 0 & 1 & 1 & 12 \\
\hline 5 & $\begin{array}{l}\text { Apakah dapat dengan mudah } \\
\text { menghindari kesalahan dalam } \\
\text { menggunakan aplikasi? }\end{array}$ & 0 & 4 & 9 & 2 \\
\hline 6 & $\begin{array}{l}\text { Apakah aplikasi bermanfaat } \\
\text { bagi pengguna? }\end{array}$ & 0 & 1 & 1 & 12 \\
\hline 7 & $\begin{array}{l}\text { Apakah aplikasi mempunyai } \\
\text { kemampuan dan fungsi } \\
\text { sesuai dengan yang } \\
\text { diharapkan? }\end{array}$ & 0 & 0 & 7 & 7 \\
\hline 8 & $\begin{array}{l}\text { Apakah aplikasi mudah } \\
\text { dioperasikan? }\end{array}$ & 0 & 2 & 7 & 5 \\
\hline 9 & $\begin{array}{l}\text { Apakah aplikasi ini mudah } \\
\text { dipelajari oleh orang yang } \\
\text { baru pertama kali } \\
\text { menggunakannya? }\end{array}$ & 0 & 3 & 8 & 3 \\
\hline 10 & $\begin{array}{l}\text { Apakah aplikasi yang } \\
\text { dihasilkan ini akurat dan } \\
\text { dapat dipercaya? }\end{array}$ & 0 & 1 & 11 & 1 \\
\hline & otal jawaban 14 koresponden & 0 & 14 & 61 & 65 \\
\hline
\end{tabular}


Pengujian kuisioner dilakukan untuk mengetahui tanggapan para peserta pengabdian (responden) terhadap aplikasi tersebut dan saran/kritik untuk pengembangan selanjutnya. Subyek berjumlah 14 peserta, yang terdiri dari 6 pemilik tambal ban dan 8 pengendara motor semua mengisi kuisioner dengan 10 pertanyaan seputar aplikasi pencarian lokasi tambal ban Banjarbaru. Dari pengujian, selanjutnya dilakukan analisa deskriptif statistik. Analisa tersebut ditampilkan pada Tabel 4. Tabel tersebut menunjukkan bahwa semua pertanyaan mendapatkan jawaban semua. Nilai rerata untuk pertanyaan nomor 1 sampai dengan nomor 7 bernilai lebih dari 3.25, sehingga dapat dinyatakan untuk ketujuh pertanyaan tersebut mendapatkan penilaian Sangat Bermanfaat. Pertanyaan nomor 8,9 dan 10 memiliki nilai rerata dalam rentang 2.5 s.d. 3.25, maka termasuk pada penilaian Bermanfaat. Teori distribusi normal dipakai untuk penyimpulan empat kategori [18] dan konversi data kualitatif menjadi data kuantitatif (skala 4) [19].

Tabel 4. Hasil Analisa Deskriptif Statistik

\begin{tabular}{|c|c|c|c|c|c|c|c|c|c|c|c|c|}
\hline \multirow{3}{*}{$\mathrm{N}$} & & & $\mathrm{p} 1$ & $\mathrm{p} 2$ & p3 & $\mathrm{p} 4$ & p5 & p6 & p7 & $\mathrm{p} 8$ & p9 & p10 \\
\hline & \multicolumn{2}{|c|}{ Valid } & 14 & 14 & 14 & 14 & 14 & 14 & 14 & 14 & 14 & 14 \\
\hline & \multicolumn{2}{|c|}{ Missing } & 0 & 0 & 0 & 0 & 0 & 0 & 0 & 0 & 0 & 0 \\
\hline \multicolumn{3}{|c|}{ Mean } & 3.50 & 3.43 & 3.57 & 3.79 & 2.79 & 3.79 & 3.50 & 3.21 & 3.00 & 3.07 \\
\hline \multicolumn{3}{|c|}{ Median } & 3.50 & 3.50 & 4.00 & 4.00 & 3.00 & 4.00 & 3.50 & 3.00 & 3.00 & 3.00 \\
\hline \multicolumn{3}{|c|}{ Mode } & $3 a$ & 4 & 4 & 4 & 3 & 4 & $3^{a}$ & 3 & 3 & 3 \\
\hline \multicolumn{3}{|c|}{ Std. Deviation } & 0.519 & 0.646 & 0.646 & 0.579 & 0.579 & 0.579 & 0.519 & 0.699 & 0.679 & 0.475 \\
\hline \multicolumn{3}{|c|}{ Variance } & 0.269 & 0.418 & 0.418 & 0.335 & 0.335 & 0.335 & 0.269 & 0.489 & 0.462 & 0.225 \\
\hline \multicolumn{3}{|c|}{ Minimum } & 3 & 2 & 2 & 2 & 2 & 2 & 3 & 2 & 2 & 2 \\
\hline \multicolumn{3}{|c|}{ Maximum } & 4 & 4 & 4 & 4 & 4 & 4 & 4 & 4 & 4 & 4 \\
\hline \multicolumn{3}{|c|}{ Sum } & 49 & 48 & 50 & 53 & 39 & 53 & 49 & 45 & 42 & 43 \\
\hline \multirow{3}{*}{\multicolumn{2}{|c|}{ Percentile }} & 25 & 3.00 & 3.00 & 3.00 & 4.00 & 2.00 & 3.00 & 3.00 & 2.75 & 3.00 & 2.00 \\
\hline & & 50 & 3.50 & 3.50 & 4.00 & 4.00 & 3.00 & 3.50 & 3.00 & 3.00 & 3.00 & 3.00 \\
\hline & & 75 & 4.00 & 4.00 & 4.00 & 4.00 & 3.00 & 4.00 & 4.00 & 3.25 & 3.00 & 3.00 \\
\hline
\end{tabular}

Hasil analisa deskriptif statistik yaitu pertanyaan dengan skor nilai (total) tertinggi dengan jumlah 53 ada di P4 (pertanyaan 4) dan P6 (pertanyaan 6), menunjukkan bahwa aplikasi ini bermanfaat bagi pengguna dan sesuai dengan kebutuhan. Sedangkan skor terendah dengan jumlah 39 ada di P5 (pertanyaan 5) yaitu apakah mudah menghindari kesalahan di aplikasi ini? Hal itu dikarenakan pada aplikasi ini belum terdapat menu tutorial untuk memudahkan pengguna (pemula) menggunakan aplikasi, tutorial hanya ada pada video yang tampil di Google Play Store.

\section{SIMPULAN}

Aplikasi mobile SIG yang dihasilkan dalam penelitian ini mampu menyediakan fitur pencarian lokasi tambal ban disertai informasinya. Penggunaan fitur tersebut diharapkan dapat bermanfaat bagi pengguna kendaraan jika mengalami kecelakaan ban atau meletus di jalan. Informasi bengkel yang disajikan ialah waktu buka/tutup bengkel, terdapat fasilitas tambah nitrogen atau tidak, tambal ban tubeless, dapat memperbaiki tambal ban motor saja atau juga bisa ban mobil serta kontak pemilik bengkel, sehingga dapat langsung menghubungi tambal ban terdekat. Hasil pengujian tanggapan pengguna terhadap penggunaan aplikasi menunjukkan bahwa aplikasi bermanfaat dan sesuai dengan kebutuhan. Penelitian selanjutnya perlu melakukan penambahan menu tutorial untuk memudahkan pengguna (pemula) menggunakan aplikasi.

\section{DAFTAR PUSTAKA}

[1] R. W. Kusuma, A. K. Yapie, and E. S. Mulyani, "Aplikasi Location Based Service (LBS) Taman Mini Indonesia Indah (TMII) Berbasis Android," in Seminar Nasional Aplikasi Teknologi Informasi 2013, 2013, no. ISSN : 1907-5022, pp. 13-18. 
[2] R. Rusli, Membuat Aplikasi GPS Ala GO-JEK, I. CV. LOKOMEDIA, 2016.

[3] I. Sugiarto, “Aplikasi Pencarian Lokasi Terdekat Pelayanan Kesehatan Berbasis Android di Yogyakarta," Sekolah Tinggi Manajemen Informatika dan Komputer AMIKOM YOGYAKARTA, 2013.

[4] A. P. Kasma, "Pemanfaatan GPS Tracker Dalam Penyediaan Informasi Pada Aplikasi Berbasis Android (Studi Kasus : Bus Transjakarta Koridor 6 Dan 6a)," Gunadarma, 2014.

[5] T. S. W. Dari, M. Zarlis, and S. Sembiring, "Pemanfaatan Google Map API pada Aplikasi Pencarian Lokasi Departemen Store Berbasis Web," Sekolah Tinggi Teknik Harapan Medan, 2013.

[6] A. A. Slameto and E. Pramono, "Inovasi Peta Digital Lokasi Bengkel Tambal Ban Untuk Smartphone," J. Teknol. Inf., vol. XIII, no. November 2017, pp. 1-10, 2018.

[7] Sutarto, "Sistem Informasi Geografi (SIG) Pembelajaran Geografi," 2015.

[8] A. Sucista, "Pembangunan Sistem Aplikasi Layanan Berbasis Lokasi Pencarian ATM dan Pom Bensin Terdekat Berbasis Android," Sekolah Tinggi Manajemen Informatika dan Komputer AMIKOM Yogyakarta, 2012.

[9] T. Ha. A. Cahyono and E. A. Supriyatno, "Alat Ukur Berat Badan, Tinggi Badan dan Suhu Badan di Posyandu Berbasis Android," $J$. ELINVO, vol. 3, no. May, pp. 31-38, 2018.

[10] S. Xianhua, D. Zhenjun, and C. Rong, "Research on mobile location service design based on Android," Proc. - 5th Int. Conf. Wirel. Commun. Netw. Mob. Comput. WiCOM 2009, 2009.

[11] N. Hasanah, Y. P. Anggara, R. H. Hidayati, and M. Riyantoro, "Smart Connector Helmet \& Automatic GPS Inovasi Alat Bantu Komunikasi antar Pengemudi dan Penunjuk Arah Berbasis
Internet," J. ELINVO, vol. 1, no. November, pp. 140-144, 2016.

[12]K. I. Santoso, “Aplikasi Location Based Service Layanan Kesehatan," J. INFOKAM, vol. I, pp. 18-27, 2016.

[13] Winardi, "Penentuan Posisi dengan GPS untuk Survei Terumbu Karang," Pulit Oseanografi LIPI, 2010.

[14]A. Pratama, “Analisis Spasial Lahan Pertanian Pangan Berkelanjutan (LP2B) di Kabupaten Pesawaran," J. Tek. Pertan. Lampung, vol. 7, no. $1,2018$.

[15]Riyanto, Membuat Sendiri Aplikasi Mobile GIS : platform Java ME, Blackberry \& Android. Yogyakarta: CV. Andi Offset (Penerbit Andi), 2010.

[16] Rismayani and H. SY, "Penerapan Tracking Bus 'Trans Mamminasata' Dengan Memanfaatkan Teknologi Google Maps API Berbasis Mobile Web di Kota Makassar," J. Penelit. Pos dan Inform., vol. 7, no. 2, pp. 129-142, 2017.

[17]H. A. Bimmo, S. T. Andrianrakhmatsyah, A. G. P. S. T, F. Teknik, U. Telkom, and G. Maps, "Perbandingan Pengukuran Jarak Tempuh Sepeda Motor antara Google Maps dan Modul GPS Berbasis Mikrokontroler Microcontroller Based Distance Measuring Comparison on Motorcycle using Google Maps and GPS Module," in e-Proceeding of Engineering, 2017, vol. 4, no. ISSN : 2355-9365, pp. 1217-1227.

[18]B. Syarifudin, Panduan TA Keperawatan dan Kebidanan Dengan SPSS. Yogyakarta: Grafindo Litera Media, 2010.

[19]D. Santoso, Slamet, P. Utami, and B. Wulandari, "Pengembangan Trainer Signal Conditioning," J. Pendidik. Teknol. dan Kejuru., vol. 13, no. 1, pp. 73-84, 2016. 